Article

\title{
Perspectives on Sustainable Forest Management in Interior Alaska Boreal Forest: Recent History and Challenges
}

\author{
Miho Morimoto * and Glenn Juday \\ School of Natural Resources and Extension, University of Alaska Fairbanks, Fairbanks, AK 99775, USA; \\ gpjuday@alaska.edu \\ * Correspondence: mmorimoto@alaska.edu; Tel.: +1-907-474-1973
}

Received: 22 April 2019; Accepted: 29 May 2019; Published: 4 June 2019

\begin{abstract}
Research Highlights: Interior Alaska boreal forest is still largely intact and forest harvest management, if applied appropriately across the forest landscape, can potentially mitigate the effects of climate warming, such as increasing wildfire and decreasing mature tree growth. Background and Objectives: This study examines historical relationships between forest growth and harvest in central boreal Alaska over the last 40 years in order to contribute to the development of sustainable forest harvesting practices. Materials and Methods: We compiled data from forest inventory and forest harvest and reforestation databases and analyzed harvesting intensity relative to growth. Results: Forest harvest management has relied heavily on natural regeneration due to a small profit margin. We found that volume harvested in the last 40 years was lower than volume growth; however, harvest activity was concentrated on the small road-accessible area and in the mature white spruce type. As a result, harvest activities need to be distributed geographically and by species in a way that prevents reduction of forest productivity or loss of ecosystem services. An expansion of the road network, or a shift in harvesting and utilization from white spruce to broadleaf would allow a significant increase in sustainable wood yield. Conclusions: There are two potential areas that could provide increased harvest, which contain a large amount of white spruce, birch, and aspen. Under rapid climate change, sustainable forest harvest management must consider the effects of fires, such as needs of salvage logging and a potential reduction of harvestable timber volumes due to damages. Forest harvest management could emulate natural fire disturbance and help reduce fuel amounts to prevent intensive and large-scale fires in the future in areas where fires are most aggressively suppressed.
\end{abstract}

Keywords: sustainable forest management; low-input management; forest harvest and regeneration management; access; Alaska boreal forest; forest inventory; wildfire; climate change

\section{Introduction}

Wood has been an important product for human living and development worldwide for thousands of years. About two thirds of boreal forests are considered to be managed [1]. In the 19th and 20th centuries, in many boreal regions (mainly northern Europe, Russia and Canada), intensive and/or extensive timber harvesting has caused a shift in forest landscapes. During this time period, the primary focus of forest management was a maximum production of wood products, often with only implicit regard for forest ecological services [2,3]. Rotation ages, which maximize the volume production and planting of single commercial tree species, have created even-aged forests with fewer old-growth stands [1,4].

However, a new appreciation has emerged on the values of forest ecological services other than wood products. Under such circumstances, sustainable forest management that aims to sustain 
multiple values of a forest, including both wood production and ecosystem services, is becoming a more important approach [5]. The boreal forest is a stand-replacement disturbance driven system, of which fire is the major disturbance [6]. Wildfire plays essential roles of creating the forest landscape mosaics [7]. As a result, one of the ways of sustainable forest management in boreal forests is to mimic wildfire disturbance [8-10].

Unlike many boreal regions, Alaska boreal forest has experienced very little forest harvest management [11] and is still largely intact [12,13]. One of the major reasons for small forestry industry is a small local demand due to low population density and a long distance from major markets, such as Seattle. In addition, forest productivity is low (Tables S1 and S2) because climate is severe, and over half of the Alaska boreal forest grows on discontinuous permafrost [1]. In Interior Alaska, relatively extensive logging occurred during the gold rush in the late 1800s to early 1900s, mainly for steamboat operations and development of urban areas [14]. Although the logging during this time period affected forest, the logging was not regulated (i.e., natural regeneration) and occurred mostly along the Yukon drainage and near a few early populations of prospectors. Due to the limited demand for forest harvest management, alternative future harvest policies are available as long as forest harvest management remains sustainable.

Climate change is a growing concern in boreal Alaska. Changing wildfire regimes, insect outbreaks and drought stress on boreal trees under climate warming are among the biggest concerns for sustainable forest management [15]. Increasing wildfire has and will modify the forest landscape by decreasing more flammable conifer and increasing early successional/more fire-resistant broadleaf stands in Interior Alaska [15]. Intensive fire suppression efforts near communities leads to a fuel buildup, which is a risk of intensive fire, especially under the new wildfire regime, as well as insect outbreaks due to declining stand health and vigor. Mature white spruce growth is also vulnerable to temperature increases [16,17]. Forest harvest management, if applied appropriately across the forest landscape, can potentially mitigate these effects of climate warming by reducing fuel amounts near communities and by regenerating healthy, vigorous stands throughout the landscape [18]. In order to optimize these opportunities, it is crucial to assess available wood resources and the intensity of wood harvesting to ensure sustained yields.

Wood biomass energy has become of interest in boreal Alaska in the last decade. As of 2015, nine wood biomass energy facilities had been built in Interior Alaska, with another 10 under construction and more than 11 in design or qualified for feasibility status [19]. Wood biomass energy can contribute to local economies by reducing dependence on fossil fuels and consequently reducing fuel costs, as well as increasing employment [20]. Wood biomass energy helps mitigate climate change effects, assuming that wood biomass is a renewable energy source (i.e., carbon emissions through combustion are offset by carbon sequestered by forest regrowth after harvesting). Due to the small forestry industry, studies of Alaska boreal forest are predominantly focused on wildfire, and studies related to forest harvest management are limited (see [14,21] for a general overview of historical forest harvest management). For sustainable forest harvest management, it is essential to understand existing forest resources and the intensity of forest harvesting.

In central Interior Alaska, forest harvest management and record keeping began in the late 1960s to 1970s. The early timber harvesting activities during the gold rush likely only occurred on a very limited area of the land base currently dedicated to sustainable forest harvest management, and information is limited [22]. As a result, in this study we only analyze forest harvest management that occurred in central Interior Alaska since the late 1960s as "historical" harvest activities. The goal of this study is to compile and analyze the history of forest harvest management in central Interior Alaska boreal forest, an area of $250,000 \mathrm{~km}^{2}$, over the last 40 years, in order to contribute to developing sustainable forest harvest and regeneration practices. 


\section{Materials and Methods}

\subsection{Study Area}

The Interior Alaska boreal region stretches from the Alaska Range in the south to the Brooks Range in the north, and the Canadian border in the east to the Chukchi Sea in the west, covering about 47 million ha (Figure 1). The climate of the study area is strongly continental. As a result, only six tree species are native to the region, including white spruce (Picea glauca (Moench) Voss), black spruce (Picea mariana (Mill.)), Alaska birch (Betula neoalaskana Sarg.), and quaking aspen (Populus tremuloides Michx.), with the minor amount of balsam poplar (Populus balsamifera L.) and tamarack (Larix laricina (Du Roi) K. Koch) [23].

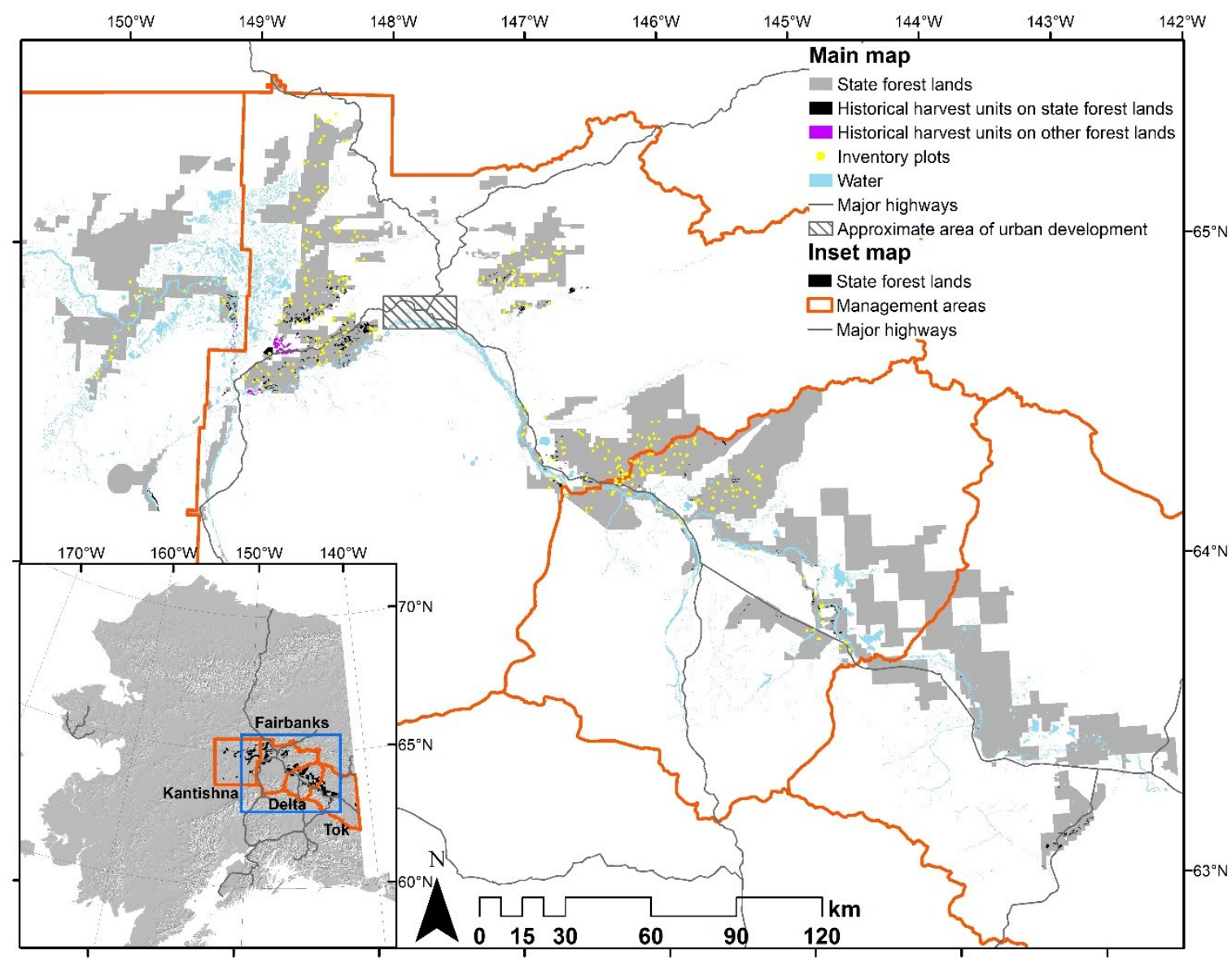

Figure 1. Maps of study area. (Inset) Study area is within the Tanana Valley of the Interior Alaska boreal region. Most of the productive forest in the area is managed by the Alaska Department of Natural Resources, Division of Forestry (AKDOF). Other ownerships included in this study include Alaska Native Corporation lands, individual Native allotments and Fairbanks North Star Borough property. (Main map) Location of the Tanana Valley State Forest and other state "forest classified" lands) which are administered in four management areas: Kantishna, Fairbanks, Delta, and Tok.

Mean annual temperature at Fairbanks International Airport (1948 to the present; elevation $133 \mathrm{~m}$ ) is $-2{ }^{\circ} \mathrm{C}$, and annual precipitation is $270 \mathrm{~mm}$, with extreme temperatures ranging from $-50{ }^{\circ} \mathrm{C}$ to $35^{\circ} \mathrm{C}$. The period between freezing temperatures in the early 21st century is approximately 123 days at Fairbanks, an increase from 85 days in the early 20th century [24]. However, climate in the region varies substantially according to factors such as elevation and aspect [25].

In the central Interior Alaska boreal region, a large area of productive forest is managed by the Alaska Department of Natural Resources, Division of Forestry (AKDOF) within the Tanana Valley, 
which is drained by the large silt-bearing Tanana River (Figure 1) [26]. The Tanana Valley State Forest and state "forest classified" lands are termed "state forest lands" in this study. State forest lands in the Tanana Basin cover 1.16 million hectares, or $2.5 \%$ of the total land area of Interior Alaska (Table 1, Figure 1), of which $\sim 75 \%$ are productive forest lands, termed "timberland" (Table 1). Of the remaining $25 \%$, approximately $15 \%$ are "dwarf forests", which grow primarily on permafrost-dominated soils. This study focuses on the timberland portion of state forest lands, because forest harvest management only occurs on timberland. The dwarf forests are mostly comprised of black spruce, which grows slowly and to only about $10 \mathrm{~m}$. The rest is either shrubland, wetland, or water feature. State forest lands are grouped into four management areas: Fairbanks, Kantishna, Delta, and Tok (Figure 1). Other major ownerships of productive forest lands within the Tanana Valley, termed "other forest lands", that are included in this analysis are the Fairbanks North Star Borough, individual Native allotments, and the Toghotthele Native Corporation (Table 1, Figure 1). There are other ownerships of productive forest lands available for wood production within the study area, but we did not include these lands in this study because of a relatively small contribution to the historical harvest and a limited data availability. This study also does not include the extensive areas of forested state and federally managed parks, wildlife refuges, and wilderness areas.

Table 1. Area of the land, timberland, and volume of wood on state and other forest lands [26]. Data was only available for Toghotthele Native Corporation lands for other forest lands.

\begin{tabular}{cccc}
\hline Management Area & Area (ha) & Timberland (ha) & Timber Volume $\mathbf{( m}^{\mathbf{3}} \mathbf{)}$ \\
\hline State forest lands & & & \\
Kantishna & 230,397 & 177,347 & $12,212,974$ \\
Fairbanks & 348,178 & 256,492 & $19,839,301$ \\
Delta & 344,686 & 258,918 & $18,046,772$ \\
Tok & 239,498 & 178,712 & $8,609,348$ \\
Totals & $1,162,760$ & 871,263 & $58,693,999$ \\
Other forest lands & & & $1,044,538$ \\
Toghotthele & 52,277 & 12,805 & \\
\hline
\end{tabular}

\subsection{Data Compilation}

In Interior Alaska, the National Forest Inventory and Analysis program only began in 2016. As a result, in this study we used forest inventory completed by the AKDOF on state forest lands and by the Toghotthele Native Corporation on their forest lands. The AKDOF inventory was done using stratified random sampling design. In each timber stand, 10 plots were typically installed, of which five were sampled for species, diameter at breast height (DBH), total tree height, bark thickness, tree vigor, crown ratio, defect type, estimated defect percentage and a coordinate. On the other five plots, trees were counted by species and size class using a relascope. The field sampling used variable radius sampling method for trees 5 inches or greater in diameter at breast height (DBH), and a fixed radius sampling method for trees smaller than 5 inches in DBH [26]. A total of 373 timber stands and 2282 plots were sampled. Based on the field measurements, timberland on state forest lands were grouped into 16 vegetation types that represented species composition and stand volume. Unsampled stands were also assigned to one of the vegetation types by interpreting aerial photography. Within each vegetation type, stand volumes per area were considered similar enough. Thus, the volume for each stand was estimated using the representative average stand volume derived from field data and the area. Inventories of Toghotthele Native Corporation lands are not spatial data, but compiled area and volume of the major vegetation types [27].

We then analyzed "historical" forest harvest activities on state and other forest lands in terms of volume and area harvested, and types of forest harvest management used from 1969 to 2012. We obtained forest harvest management databases from the AKDOF's Fairbanks and Tok area offices [28]. The Fairbanks area office managed Fairbanks, Kantishna, and Delta management areas at the time of 
database acquisition. For other forest lands, we obtained the forest harvest management databases from Tanana Chiefs Conference (TCC).

The databases contain records of timber harvesting and reforestation, such as geographical location, type and date of harvest, site preparation, reforestation, contractor, and harvest area [28,29]. We made corrections to the databases to increase accuracies of analyses, and simplified methods of forest harvest management. Inconsistencies and incomplete records of date of harvest were a particular problem. The recorded date of harvest may only be the transaction date, and actual timber harvesting may have occurred over a number of years. We specified year of harvest using either year/date of harvest, expiration or terminated date of timber sale, timber sale files, and/or aerial photography from 2006 and 2012, depending on data availability. Even after the data adjustments and additions, year of harvest is missing for several harvests, especially in Tok (103 missing out of 137 recorded).

Before harvesting, timber volume to be sold is determined for sawlogs (trees larger than $22.86 \mathrm{~cm}$ (9 inches) in DBH) and fuelwood across the entire timber sale. However, actual volume harvested could be slightly lower than the recorded volume, because some undesirable stems (e.g., small, defective) might have been left standing, even if they were included in the contract. However, we believe that the discrepancy is minimal.

Some geographical information contains errors, especially in old harvests. In the 1970s, some large harvests were laid out across a large forest area, and harvesting was allowed anywhere within the boundary (Doug Hanson, personal communication). This resulted in some mapped harvest units in the database that were larger than the actual area harvested. Aerial photography was used to supplement any missing or incomplete data as best as possible. However, availability is limited and a complete reconstruction of the databases was beyond our scope of work, even if possible.

\subsection{Analysis}

Forest composition and structure were summarized using forest inventories conducted by the AKDOF and the Toghatthele Native Corporation. Average stand age, area, timber volume, volume per area, average annual growth, and annual growth of each timberland vegetation type were compiled for state forest lands. In Interior Alaska, the National Forest Inventory and Analysis program just began in 2016, and reliable long-term growth data are not available. As a result, average annual growth is estimated by dividing the timber volume of each vegetation type by average stand age (Tables 2-5). This method of growth estimate depicts the stand growth rate over the entire life span, including mortality events, both at an individual and stand level (e.g., fire disturbance). Historical wildland fire data were also compiled, because fire is the major disturbance in the boreal forest. The fire data were obtained from Alaska Interagency Coordination Center [30].

We summarized area harvested by management types. Methods of harvesting and regeneration management were each simplified into a few categories for a more meaningful interpretation. Harvesting method was placed into one of seven categories (see Section 3.2). Site preparation technique was simplified into two categories (none vs scarification) by combining all scarification types into a single category. Reforestation method was classified as natural regeneration or artificial reforestation, regardless of type, species, timing, or frequency/density of artificial reforestation. Regeneration management was not recorded in Delta and Tok management areas.

Historical trends of harvest activities on state forest lands and other forest lands between 1969 and 2012 were identified. We analyzed the volume harvested of white spruce sawlogs, white spruce fuelwood, birch, and aspen by year. Birch and aspen were predominantly harvested for fuelwood and were not classified by product types. 
Table 2. Average stand age, area, timber volume, volume per area, average annual growth, and annual growth of each timberland vegetation type on state forest lands (Fairbanks management area).

\begin{tabular}{|c|c|c|c|c|c|}
\hline Vegetation Types & Average Stand Age & Area (ha) & Volume $\left(\mathrm{m}^{3}\right)$ & Volume per Area $\left(\mathrm{m}^{3} \mathrm{ha}^{-1}\right)$ & Annual Growth $\left(\mathrm{m}^{3} \mathrm{yr}^{-1}\right.$ \\
\hline White Spruce Sawtimber & 175 & 10,690 & $2,355,962$ & 220 & 13,463 \\
\hline White Spruce Poletimber & 165 & 9789 & $1,633,214$ & 167 & 9898 \\
\hline Birch Closed & 96 & 30,748 & $3,667,865$ & 119 & 38,207 \\
\hline Birch Open & 117 & 3269 & 279,520 & 86 & 2389 \\
\hline Aspen Closed & 94 & 12,034 & $1,929,125$ & 160 & 20,523 \\
\hline Aspen Open & 108 & 552 & 56,893 & 103 & 527 \\
\hline Birch-Aspen Closed & 100 & 6934 & 864,111 & 125 & 8641 \\
\hline Birch-Aspen Open & 111 & 2576 & 256,634 & 100 & 2312 \\
\hline White Spruce-Birch Sawtimber & 168 & 9991 & $1,542,952$ & 154 & 9184 \\
\hline White Spruce-Birch Poletimber & 132 & 16,333 & $1,729,193$ & 106 & 13,100 \\
\hline White Spruce-Birch-Aspen Sawtimber & 119 & 4766 & 778,980 & 163 & 6546 \\
\hline White Spruce-Birch-Aspen Poletimber & 117 & 8305 & $1,048,337$ & 126 & 8960 \\
\hline White Spruce-Balsam Poplar & 100 & 3572 & 380,708 & 107 & 3807 \\
\hline Black and White Spruce-Birch-Aspen & 127 & 6385 & 603,563 & 95 & 4752 \\
\hline White Spruce-Hardwood Reproduction & 56 & 62,033 & $1,801,351$ & 29 & 32,167 \\
\hline $\begin{array}{c}\text { Black and White Spruce-Hardwood } \\
\text { Reproduction }\end{array}$ & 92 & 68,515 & 910,894 & 13 & 9901 \\
\hline White spruce sawtimber type total & & 25,447 & $4,677,894$ & & 29,193 \\
\hline Birch type total & & 34,215 & $4,099,920$ & & 42,527 \\
\hline Aspen type total & & 15,501 & $2,361,181$ & & 24,843 \\
\hline Timberland total & & 256,492 & $19,839,301$ & & 184,377 \\
\hline
\end{tabular}


Table 3. Average stand age, area, timber volume, volume per area, average annual growth, and annual growth of each timberland vegetation type on state forest lands (Kantishna management area).

\begin{tabular}{|c|c|c|c|c|c|}
\hline Vegetation Types & Average Stand Age & Area (ha) & Volume $\left(\mathrm{m}^{3}\right)$ & Volume per Area $\left(\mathrm{m}^{3} \mathrm{ha}^{-1}\right)$ & Annual Growth $\left(\mathrm{m}^{3} \mathrm{yr}^{-1}\right)$ \\
\hline White Spruce Sawtimber & 175 & 6059 & $1,335,435$ & 220 & 7631 \\
\hline White Spruce Poletimber & 165 & 4390 & 732,280 & 167 & 4438 \\
\hline Birch Closed & 96 & 26,761 & $3,188,918$ & 119 & 33,218 \\
\hline Birch Open & 117 & 1048 & 89,620 & 86 & 766 \\
\hline Aspen Closed & 94 & 6202 & 994,231 & 160 & 10,577 \\
\hline Aspen Open & 108 & 83 & 8522 & 103 & 79 \\
\hline Birch-Aspen Closed & 100 & 9274 & $1,155,690$ & 125 & 11,557 \\
\hline Birch-Aspen Open & 111 & 900 & 89,706 & 100 & 808 \\
\hline White Spruce-Birch Sawtimber & 168 & 3727 & 575,591 & 154 & 3426 \\
\hline White Spruce-Birch Poletimber & 132 & 8555 & 905,691 & 106 & 6861 \\
\hline White Spruce-Birch-Aspen Sawtimber & 119 & 445 & 72,708 & 163 & 611 \\
\hline White Spruce-Birch-Aspen Poletimber & 117 & 5200 & 656,421 & 126 & 5610 \\
\hline White Spruce-Balsam Poplar & 100 & 1858 & 197,968 & 107 & 1980 \\
\hline Black and White Spruce-Birch-Aspen & 127 & 2457 & 232,267 & 95 & 1829 \\
\hline White Spruce-Hardwood Reproduction & 56 & 40,859 & $1,186,488$ & 29 & 21,187 \\
\hline $\begin{array}{c}\text { Black and White Spruce-Hardwood } \\
\text { Reproduction }\end{array}$ & 92 & 59,530 & 791,440 & 13 & 8603 \\
\hline White spruce sawtimber type total & & 10,231 & $1,983,733$ & & 29,193 \\
\hline Birch type total & & 31,398 & $3,766,763$ & & 42,527 \\
\hline Aspen type total & & 10,839 & $1,572,076$ & & 24,843 \\
\hline Timberland total & & 177,347 & $12,212,974$ & & 184,377 \\
\hline
\end{tabular}


Table 4. Average stand age, area, timber volume, volume per area, average annual growth, and annual growth of each timberland vegetation type on state forest lands (Delta management area).

\begin{tabular}{|c|c|c|c|c|c|}
\hline Vegetation Types & Average Stand Age & Area (ha) & Volume $\left(\mathrm{m}^{3}\right)$ & Volume per Area $\left(\mathrm{m}^{3} \mathrm{ha}^{-1}\right)$ & Annual Growth $\left(\mathrm{m}^{3} \mathrm{yr}^{-1}\right.$ \\
\hline White Spruce Sawtimber & 175 & 8146 & $1,795,383$ & 220 & 10,259 \\
\hline White Spruce Poletimber & 165 & 11,574 & $1,930,782$ & 167 & 11,702 \\
\hline Birch Closed & 96 & 19,923 & $2,374,088$ & 119 & 24,730 \\
\hline Birch Open & 117 & 2072 & 177,140 & 86 & 1514 \\
\hline Aspen Closed & 94 & 9051 & $1,451,011$ & 160 & 15,436 \\
\hline Aspen Open & 108 & 437 & 45,017 & 103 & 417 \\
\hline Birch-Aspen Closed & 100 & 13,792 & $1,718,810$ & 125 & 17,188 \\
\hline Birch-Aspen Open & 111 & 914 & 91,055 & 100 & 820 \\
\hline White Spruce-Birch Sawtimber & 168 & 4929 & 761,108 & 154 & 4530 \\
\hline White Spruce-Birch Poletimber & 132 & 10,202 & $1,080,039$ & 106 & 8182 \\
\hline White Spruce-Birch-Aspen Sawtimber & 119 & 1906 & 311,491 & 163 & 2618 \\
\hline White Spruce-Birch-Aspen Poletimber & 117 & 20,665 & $2,608,517$ & 126 & 22,295 \\
\hline White Spruce-Balsam Poplar & 100 & 3175 & 338,327 & 107 & 3383 \\
\hline Black and White Spruce-Birch-Aspen & 127 & 7319 & 691,851 & 95 & 5448 \\
\hline White Spruce-Hardwood Reproduction & 56 & 47,439 & $1,377,560$ & 29 & 24,599 \\
\hline $\begin{array}{c}\text { Black and White Spruce-Hardwood } \\
\text { Reproduction }\end{array}$ & 92 & 97,376 & $1,294,592$ & 13 & 14,072 \\
\hline White spruce sawtimber type total & & 14,980 & $2,867,983$ & & 29,193 \\
\hline Birch type total & & 26,819 & $3,233,493$ & & 42,527 \\
\hline Aspen type total & & 15,948 & $2,310,416$ & & 24,843 \\
\hline Timberland total & & 258,918 & $18,046,772$ & & 184,377 \\
\hline
\end{tabular}


Table 5. Average stand age, area, timber volume, volume per area, average annual growth, and annual growth of each timberland vegetation type on state forest lands (Tok management area).

\begin{tabular}{|c|c|c|c|c|c|}
\hline Vegetation Types & Average Stand Age & Area (ha) & Volume $\left(\mathrm{m}^{3}\right)$ & Volume per Area $\left(\mathrm{m}^{3} \mathrm{ha}^{-1}\right)$ & Annual Growth $\left(\mathrm{m}^{3} \mathrm{yr}^{-1}\right.$ \\
\hline White Spruce Sawtimber & 163 & 4568 & 815,701 & 179 & 5004 \\
\hline White Spruce Poletimber & 159 & 12,548 & $1,302,113$ & 104 & 8189 \\
\hline Birch Closed & 112 & 3883 & 225,266 & 58 & 2011 \\
\hline Birch Open & 110 & 616 & 30,222 & 49 & 275 \\
\hline Aspen Closed & 95 & 3295 & 283,114 & 86 & 2980 \\
\hline Aspen Open & 85 & 1031 & 36,930 & 36 & 434 \\
\hline Birch-Aspen Closed & 96 & 1228 & 106,322 & 87 & 1108 \\
\hline Birch-Aspen Open & 113 & 140 & 10,834 & 77 & 96 \\
\hline White Spruce-Birch Sawtimber & 188 & 443 & 54,489 & 123 & 290 \\
\hline White Spruce-Birch Poletimber & 134 & 4365 & 313,363 & 72 & 2339 \\
\hline White Spruce-Birch-Aspen Sawtimber & 119 & 475 & 46,048 & 97 & 387 \\
\hline White Spruce-Birch-Aspen Poletimber & 142 & 9778 & 861,374 & 88 & 6066 \\
\hline White Spruce-Balsam Poplar & 136 & 2483 & 383,312 & 154 & 2818 \\
\hline Black and White Spruce-Birch-Aspen & 111 & 1672 & 81,899 & 49 & 738 \\
\hline White Spruce-Hardwood Reproduction & 79 & 71,987 & $2,815,725$ & 39 & 35,642 \\
\hline $\begin{array}{c}\text { Black and White Spruce-Hardwood } \\
\text { Reproduction }\end{array}$ & 99 & 60,200 & $1,242,635$ & 21 & 12,552 \\
\hline White spruce sawtimber type total & & 5486 & 916,238 & & 29,193 \\
\hline Birch type total & & 4498 & 278,427 & & 42,527 \\
\hline Aspen type total & & 3909 & 336,275 & & 24,843 \\
\hline Timberland total & & 178,712 & $8,609,348$ & & 184,377 \\
\hline
\end{tabular}


For a basis of assessment of sustainable forest management, we first compared annual volume harvested to annual volume growth on the entire timberland on state forest lands. The comparisons were made for white spruce sawlogs, birch, and aspen. The volume growth of white spruce sawlogs was assumed to be the sum of any sawlog vegetation types (white spruce sawlogs, white spruce-birch sawlogs, and white spruce-birch-aspen sawlogs). Sawlog types contained other species than white spruce and smaller diameter trees, but a majority of the volume of sawlog types was made up of white spruce sawlog. This is a conservative estimate because white spruce sawlogs are also present in other vegetation types, and some vegetation types (especially broadleaf types) eventually turn into white spruce stands as broadleaf mature and die [7]. We summed volume growth of birch closed and a half of birch-aspen closed for birch volume growth. Similarly, aspen closed and a half of birch-aspen closed were summed for aspen volume growth. These volume growth estimates for broadleaf are conservative, because broadleaf fuelwood is often harvested along with white spruce sawlogs. "Volume harvested" excludes salvage logged wood, because salvage logging harvests burned trees after fires and is not part of the inventoried volume that makes up of volume growth of white spruce sawlog, birch, or aspen. This analysis was only done on state forest lands because volume harvested on other forest lands was recorded in board feet, which is not directly convertible to cubic meters.

Access is a major constraint on forest harvest management in Interior Alaska [14]. As a result, the comparisons of annual volume harvested and annual volume growth were also analyzed in zones of $1 \mathrm{~km}$ intervals up to $4 \mathrm{~km}$ and further than $4 \mathrm{~km}$ from the nearest road feature. The AKDOF data layer for road features includes highways, primary all-season or winter roads, secondary all-season or winter roads, and spur roads, which is a short temporary road for a specific forest management practice, such as timber harvesting (Doug Hanson, personal communication [31]). We included all roads existing as of 2013 in the AKDOF road data layer [28], although some of the roads might not have existed at the time of harvest. However, forest roads are generally built when access to harvest is required, so the error in the distance to road parameter is marginal. We also added forest roads using aerial photography to the best of our ability.

We examined the number of harvested units and volume harvested that fell within the zones. We also identified available timber volumes of white spruce sawlogs, birch, and aspen within each zone. We then compared the annual volume harvested and the annual volume growth of white spruce sawlogs, birch, and aspen to determine the intensity of harvesting activities between 1972 and 2012. The annual volume growth for white spruce sawlogs, birch, and aspen was estimated using the same method as described earlier (i.e., timber volume divided by average stand age; Tables 2-5). We also produced maps of white spruce sawlogs and birch types on state forest lands by distance to the nearest road $(1,2,3,4$, and $>4 \mathrm{~km})$ to analyze timber accessibility.

\section{Results and Discussion}

\subsection{Forest Composition and Structure}

On state forest lands, the greatest area of forest cover is black spruce-white spruce-broadleaf forest, and white spruce-broadleaf forest (36\% and 30\% of timberland, respectively; Tables $2-5$ ). Extensive areas of mixed black spruce forest occur on cold soils underlain by permafrost. Permafrost dominated sites, because of their low forest productivity, are generally not harvested [32,33]. However, wood biomass harvesting, which harvests trees for energy generation, is expanding. Alaska is unique in that trees are harvested exclusively for energy generation, unlike other regions where harvest residues are used for such purposes. Wood biomass harvesting could potentially utilize black spruce material, which conventionally is too small to be profitable, and harvesting of this type may expand in the future. In contrast, white spruce is the most productive stand type in central Interior Alaska (Tables 2-5), except for balsam poplar, which covers a small area in floodplains [34]. Pure white spruce (20\%) and mixed white spruce and broadleaf types (37\%) contain the greatest wood volume on state forest lands 
(57\%; Tables 2-5). As a result, during the period of analysis, most timber harvesting occurred of white spruce types.

On other forest lands (only including inventory of Toghotthele lands; see Section 2.2), pure or mixed white spruce forest covers the greatest area $(69 \%)$, and broadleaf forest covers about one fourth of the land. This is because the land was selected mainly for productive forest lands for wood production. Wood volume on other forest lands is mostly composed of pure white spruce (36\%), mixed white spruce and broadleaf ( $45 \%)$, and broadleaf types ( $18 \%)$.

The landscape of the Alaska boreal forest is shaped mainly by wildfire disturbances. Between 1943 and 2017, 42\% of total lands in Interior Alaska burned at least once [30]. This figure does not exclude non-forest lands, indicating the proportion of area burned within the boreal forest is higher than $42 \%$. More than half of those areas within the fire perimeter burned twice or more in the 75-year period. Average fire return interval is estimated between 50-200 years [35,36]. As a result, forest stands rarely reach 200 years (Figures 2 and 3). About $60 \%$ of timberland on state forest lands is reproduction (due to any type of disturbance, including timber harvesting; Tables 2-5) and 20\% of timberland stands are under 10 years old (Figure 3).

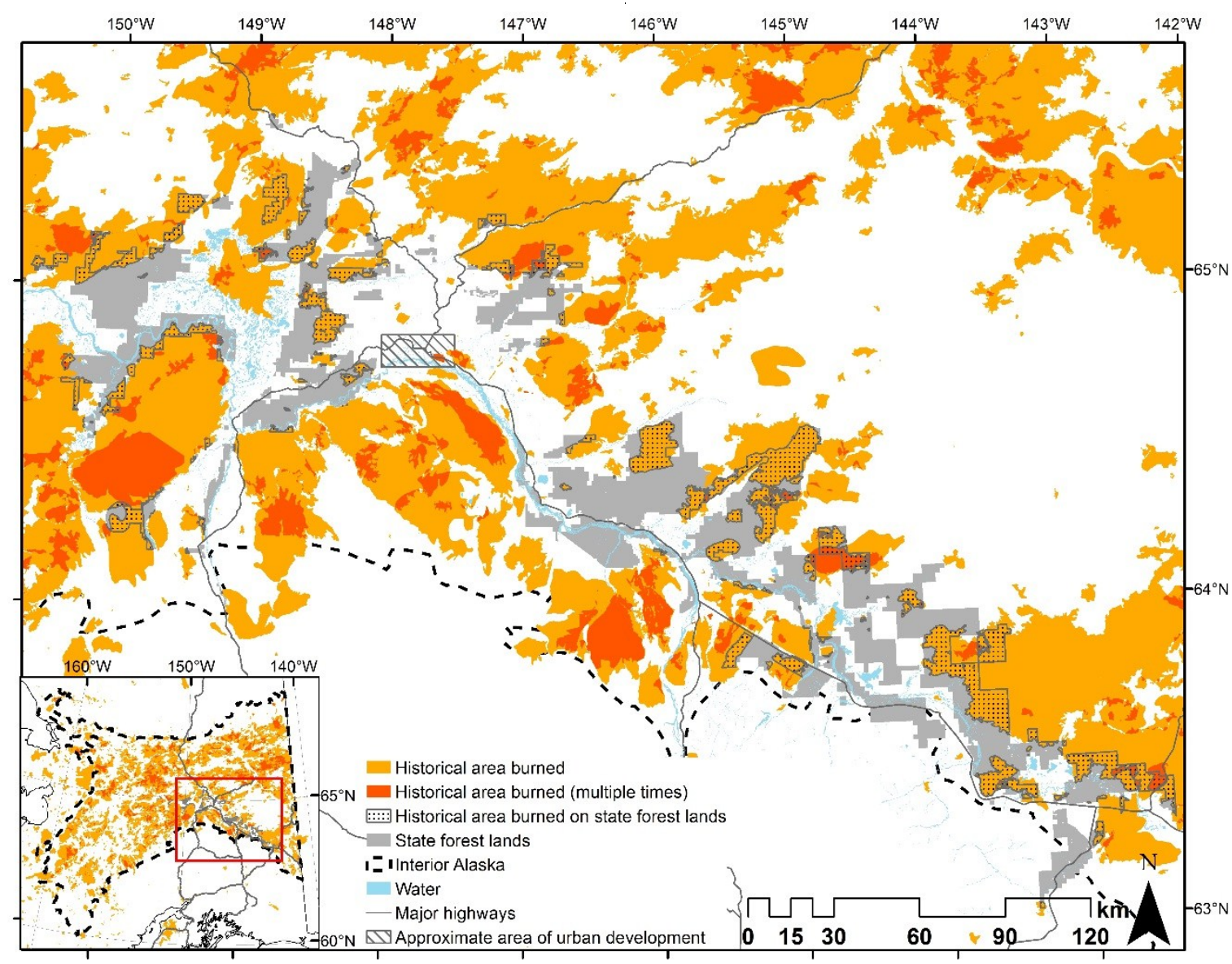

Figure 2. Historical wildfire perimeters between 1943 and 2017. 


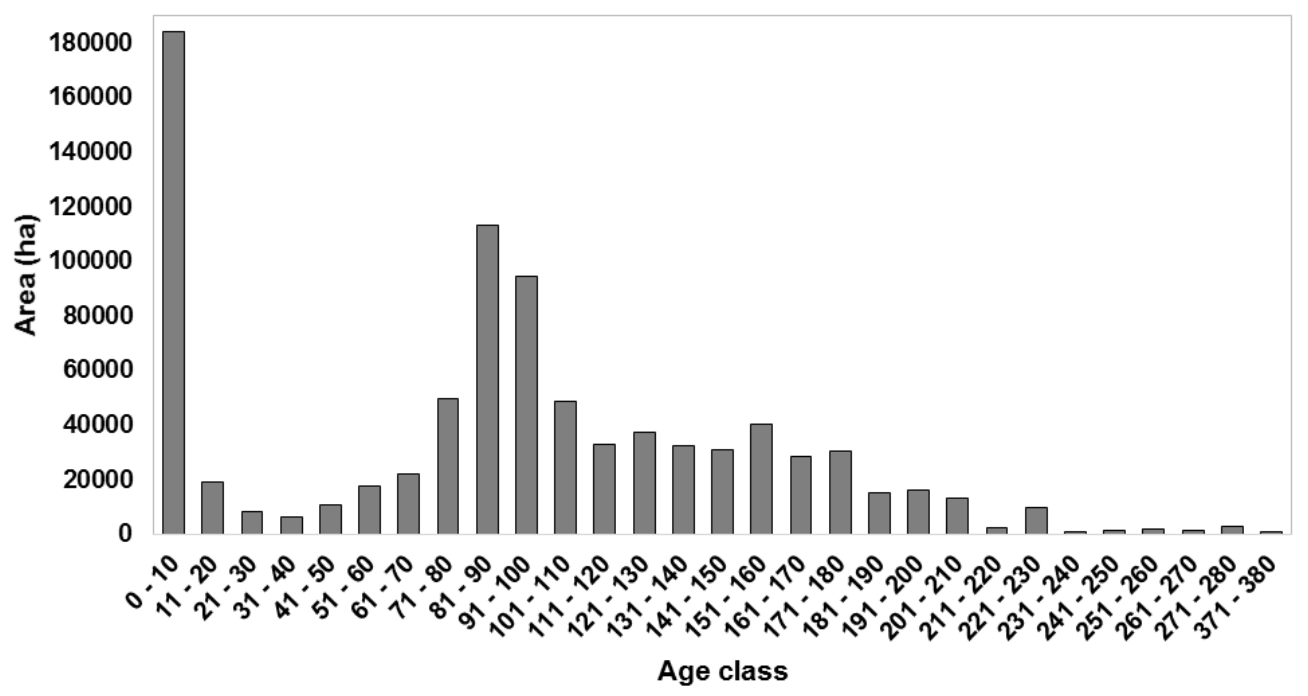

Figure 3. Stand age class distribution (area in ha) of timberland on state forest lands.

\subsection{Types of Forest Harvest Management Used in the Study Area}

Clearcutting and selection cutting (18\% and 39\% of total area harvested, respectively) were two major harvesting methods used in the study area. Clearcutting is supposed to remove all stems, large or small, in the stand; however, in the study area, even if the harvesting method is prescribed as clearcutting, loggers may leave undesirable stems, such as small diameter trees and broadleaf stems. In the study area, selection cutting was in general a high grading method that removed the best trees. In the study area, large white spruce was predominantly harvested for the selection cutting (approximately $70 \%-80 \%$ of selection cutting). Salvage logging (13\% of total area harvested) was another major forest management practice applied in the study area, and was used mainly after the Rosie Creek Fire in 1983 that burned 2677 ha of state forest lands.

Assisted regeneration following a harvest is a common forest management practice in many boreal regions. In the study region, the two most common post-harvest regeneration practices were site preparation and planting of seedlings. Depth of organic layer is one of the most important factors determining post-disturbance natural regeneration in Interior Alaska [37], and removal of the organic layer (which naturally happens when fire burns the organic layer) promotes establishment of new vegetation. Site preparation exposes a mineral substrate that many species require for successful germination, while reducing the remaining vegetation that competes with tree regeneration $[37,38]$. Species competing with white spruce, especially Calamagrostis canadensis, spread rapidly by below-ground rhizomes after disturbance [39]. White spruce, on the other hand, regenerates predominantly from seed, and grows slower than most other early successional tree species [40]. As a result, removing the organic layer and below-ground rhizomes of competitive species helps enhance white spruce regeneration. In addition, white spruce regeneration is limited by other factors [40], including sporadic seed production [41-43] and dispersal ability [44]. As a result, site preparation and planting white spruce seedlings, when applied on state forest lands, are often used in combination. Despite these limitations in regeneration, post-harvest regeneration management has been applied at a very limited scale, mainly due to limited funding. In Alaska, artificial reforestation is required when natural regeneration is not adequate to meet the state stocking standard (450 stems per acre), and the AKDOF is responsible for the regeneration survey and, when necessary, reforestation. The AKDOF is also responsible for the wildfire management of 62 million hectares of lands, and most forest management resources are used for wildfire management (about $95 \%$ of funding) [45]. As a result, forest harvest management needs to be economically self-sustained. Timber harvest revenue is marginal, especially when demand is low, and forest resource management in general is expensive, mainly due to the large area and limited access. A recent study, however, found that natural regeneration is adequate 
after white spruce harvesting without reforestation [46,47]. It is also important to point out that natural regeneration may take longer to regenerate forest stands than artificial reforestation, but depending on the management goal, natural regeneration may be more suitable than artificial reforestation (e.g., when the goal is to create wildlife habitat).

The predominant method for site preparation in Interior Alaska has been mechanical site preparation using heavy equipment. Prescribed burning and the application of herbicide have been limited to experimental purposes during the study period in central Interior Alaska [48], unlike many other forest regions [49,50]. Planting of white spruce seedlings has been the predominant method for artificial reforestation. Some introduced species were planted experimentally at a very limited scale, including lodgepole pine (Pinus contorta var. latifolia Engelm. Dougl. ex Loud), Siberian larch (Larix sibirica Ledeb.), and Scotch pine (Pinus sylvestris L.) in the Fairbanks area. Out of the total 3223 ha planted in the area, 74 ha (2.3\%) were planted with introduced species exclusively, and 162 ha (5\%) were planted with mixed white spruce and introduced species.

On state forest lands, site preparation and artificial reforestation increased in the mid-1980s and 1990s, when total harvest area increased particularly because of the large burned forest area harvested after the Rosie Creek Fire and the associated salvage and sanitation logging [51]. Almost half the area that received any post-harvest regeneration practice was salvage logged, and about one third of the total harvested area was clearcut, which was used mostly during the period of greatest harvest activity. Site preparation used only $18 \%$ of the harvested area (Table 6). Artificial/assisted reforestation has been used on about half of harvested area (Table 6).

Table 6. Areas of timberland and harvest (ha), and area (ha) and \% of harvested areas which received site preparation and reforestation in the study area for the period of 1972-2012. FNSB = Fairbanks North Star Borough ownership.

\begin{tabular}{|c|c|c|c|c|c|c|}
\hline & \multirow{3}{*}{$\begin{array}{c}\text { Timberland } \\
\text { (ha) }\end{array}$} & \multicolumn{5}{|c|}{ Harvested Area } \\
\hline & & \multirow{2}{*}{$\begin{array}{l}\text { Harvest } \\
\text { (ha) }\end{array}$} & \multicolumn{2}{|c|}{ Site Preparation } & \multicolumn{2}{|c|}{ Reforestation } \\
\hline & & & (ha) & $(\%)$ & (ha) & $(\%)$ \\
\hline \multicolumn{7}{|l|}{ State forest lands } \\
\hline Fairbanks & 256,284 & 6881 & 1283 & $19 \%$ & 3329 & $48 \%$ \\
\hline Kantishna & 177,348 & 436 & 0 & $0 \%$ & 103 & $24 \%$ \\
\hline Delta & 258,919 & 1229 & na & na & na & na \\
\hline Tok & 178,712 & 890 & na & na & na & na \\
\hline State forest lands total & 871,263 & 9435 & 1283 & $18 \%$ & 3432 & $47 \%$ \\
\hline \multicolumn{7}{|l|}{ Other forest lands } \\
\hline Toghotthele & 12,805 & 2560 & 831 & $32 \%$ & 260 & $10 \%$ \\
\hline FNSB & NA & 122 & 5 & $4 \%$ & 20 & $16 \%$ \\
\hline Native allotment & NA & 80 & 10 & $12 \%$ & 80 & $100 \%$ \\
\hline $\begin{array}{l}\text { Other forest lands } \\
\text { total }\end{array}$ & 12,805 & 2762 & 846 & $31 \%$ & 359 & $13 \%$ \\
\hline Total & 884,067 & 12,197 & na & na & na & na \\
\hline
\end{tabular}

Site preparation on other forest lands was only used before 1980, with a total of $31 \%$ of the harvested area (Table 6). Only 13\% of the area harvested on other forest lands was planted with white spruce seedlings (Table 6). Unlike state forest lands, site preparation on other forest lands was used alone (without planting) in the majority of cases.

\subsection{Transition of Forest Harvest Management}

Harvested area and volume to date in Interior Alaska boreal forest since the late 1960s are small, particularly considering the vast total area and large total timber volume of the forest (Tables 1-5). The total area harvested on state forest lands from the start of record collection in 1972 to 2012 is about 9435 ha out of 871,263 ha of total timberland on state forest lands (Table 6), or 1.1\%. Harvest activity on state forest lands was continuous from the early 1970s, with great variability among years (Figure 4). 
(a)

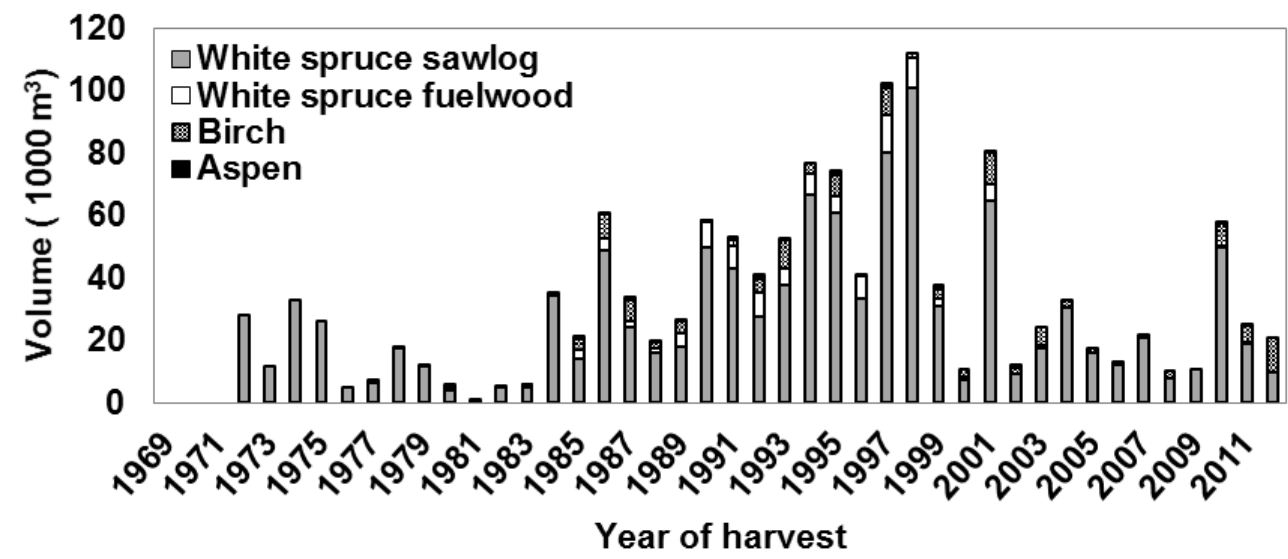

(b)

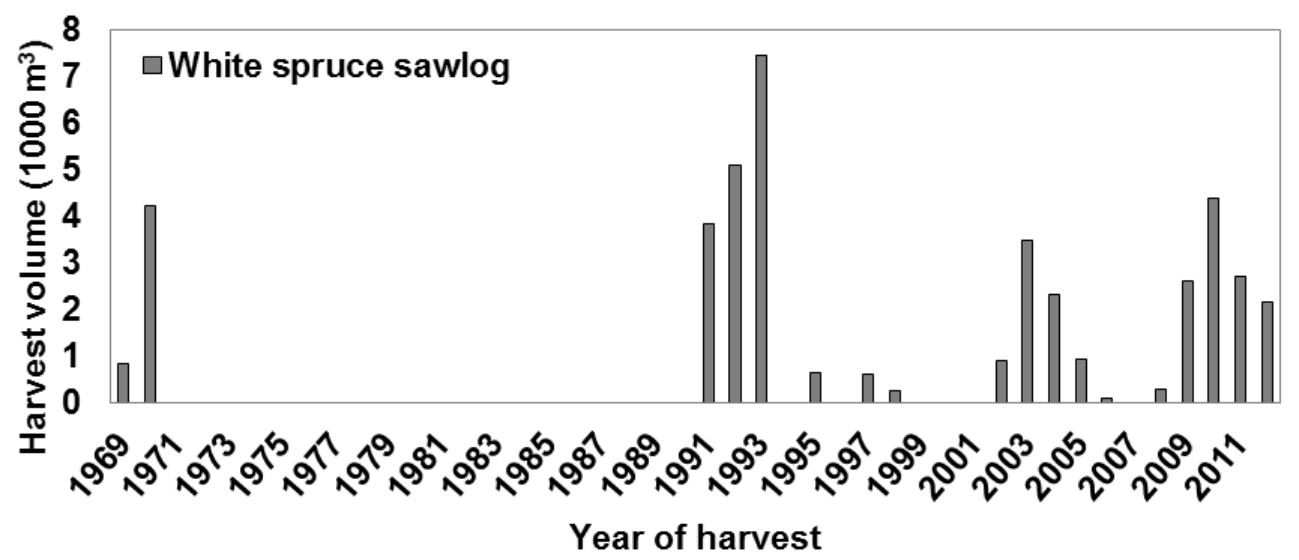

Figure 4. Annual volume harvested $\left(1000 \mathrm{~m}^{3}\right)$ by species/product on (a) state forest lands from 1972 to 2012, and (b) other forest lands from 1969 to 2012. For other forest lands, the volumes were measured in board feet, which is not directly convertible to cubic meters. We simply multiplied the values in board feet by 0.00235974 , which results in errors. The volume data are missing on both state forest lands ( $10 \%$ of area harvested) and other forest lands ( $20 \%$ of area harvested). On other forest lands, volume data are missing on units harvested in 1976 and 1981. On state forest lands, year of harvest is also missing for those units missing volume data.

On state forest lands, annual area and volume harvested were quite low from 1972 until the early 1980s. In the mid-1980s, harvest area and volume gradually increased until the early 1990s in response to salvage and sanitation harvesting following a large fire in 1983 that burned 3500 ha of state forest lands [51]. The priority after this fire was to salvage trees killed or damaged, and to recoup valuable timber before decay and prevent the spread of insect outbreaks from injured to healthy trees [51]. A total of approximately 1200 ha was salvage logged due to the fire. Across all state forest lands, the total white spruce fuelwood volume harvested in the last 40 years is only $78,050 \mathrm{~m}^{3}$, and nearly half of that volume came from salvage logging in the late-1980s and 1990s.

In the 1990s, as salvage logging from the 1983 fire was being completed, clearcutting increased rapidly in response to increased demand for spruce sawlogs in the Asian market (Figure 4a) [14]. In many boreal regions, homogenous forest (e.g., even-aged and/or single-species) created by extensive clearcutting and planting is subject to management efforts, such as intensive planting, to restore heterogeneous forest structures and a diversity of species habitats [8]. Partial cutting is one of the management practices used to restore forest diversity [9]. In the late 1990s, such concerns, along with a 
decreasing demand due to the downturn of wood product demand in the Asian market, resulted in a shift in the major harvesting method from clearcutting to partial cutting on state forest lands (Figure 4a). Overall harvest area and volume also decreased and remained low for the rest of the study period.

On other forest lands, harvest activity has occurred sporadically, with a few peaks over the last few decades (Figure 4b) when timber harvesting has been economically viable. During the period of analysis, harvest activities on other forest lands were lower than on state forest lands (Table 6). However, the volume harvested on other forest lands contains errors, because the volume was only recorded in board feet, which measures the volume of processed boards and not the volume of the entire log. The greatest area of harvesting occurred on Toghotthele lands (Table 6). Harvested area on other forest lands peaked in 1969, 1976, and 1979, but harvest volumes were not recorded for 1976 and 1981.

\subsection{Perspectives on Sustainable Forest Management}

A comparison of harvest intensities to forest growth provides a perspective on the relative degree or magnitude of utilization of wood volume. Throughout the period of our analysis, the mean annual volume harvested of white spruce and especially birch and aspen were lower than the annual volume growth of white spruce sawlogs, birch, and aspen types, respectively, on the entire timberlands on state forest lands (Table 7). Harvest volume of all white spruce, birch, and aspen were four to five times greater in the Fairbanks area than other areas, but even there harvested volumes were 64\%, 5\%, and $1 \%$ of annual volume growth for white spruce, birch, and aspen, respectively.

Table 7. Comparison between volume harvested and annual growth for each product type and management area.

\begin{tabular}{ccccc}
\hline & Fairbanks & Kantishna & Delta & Tok \\
\hline White spruce sawlogs & & & & \\
Annual harvest $\left(\mathrm{m}^{3}\right)$ & 18,701 & 1137 & 2959 & 665 \\
Annual growth $\left(\mathrm{m}^{3}\right)$ & 29,193 & 11,668 & 17,407 & 5681 \\
Harvest/Growth & $64 \%$ & $10 \%$ & $17 \%$ & $12 \%$ \\
Birch & & & & \\
Annual harvest $\left(\mathrm{m}^{3}\right)$ & 2232 & 15 & 31 & na \\
Annual growth $\left(\mathrm{m}^{3}\right)$ & 42,527 & 38,996 & $0 \%, 324$ & na \\
Harvest/Growth & $5 \%$ & $0 \%$ & & na \\
Aspen & & & 5 & 3534 \\
Annual harvest $\left(\mathrm{m}^{3}\right)$ & 205 & 0 & 24,030 & na \\
Annual growth $\left(\mathrm{m}^{3}\right)$ & 24,843 & 16,355 & $0 \%$ & $0 \%$ \\
Harvest/Growth & $1 \%$ & $0 \%$ & & \\
\hline
\end{tabular}

White spruce sawlogs were the major harvested product category, accounting for about $90 \%$ of harvested volume on state forest lands. A total of $961,967 \mathrm{~m}^{3}$ white spruce sawlogs were harvested from state forest lands during the 1972-2012 period, which is 37\% of the total volume growth of white spruce sawlog types estimated for the time period. The overall mean volume of annual white spruce harvested is $23,463 \mathrm{~m}^{3}$, with great variability among years (Figure $4 \mathrm{a}$ ). Although the overall mean annual harvested volume of white spruce sawlogs was lower than the annual growth (Table 7), the harvested volume of white spruce sawlogs exceeded the annual volume growth in some years, especially during the 1990s. In the Fairbanks management area, annual harvested volume surpassed the mean annual growth rate in 8 out of 41 years, which is much greater than other management areas. The number of years exceeding the mean annual volume growth are 1, 1, and 2, for Kantishna, Delta, and Tok management areas, respectively.

Birch and aspen are minor harvested species compared to white spruce in the study area. A total of $93,804 \mathrm{~m}^{3}$ birch and $8607 \mathrm{~m}^{3}$ of aspen were harvested from state forest lands during the study period. However, birch harvest volume has increased in the most recent years (Figure $4 \mathrm{a}$ ), reflecting 
increased interest in wood biomass energy [20]. Wood biomass is renewable energy that can mitigate climate change as long as the net carbon emissions of the wood energy harvest (i.e., carbon emission less carbon sequestered during regeneration) are less than those of energy generated by fossil fuels and the biomass harvest does not cause a reduction in long-term forest productivity. Wood biomass can also stimulate local economies, especially in rural Alaska, by decreasing dependence on imported fuel and creating local employment. Based strictly on the perspective of the relationship of volume harvested versus growth across the analysis area as a whole, the current low level of birch and aspen harvesting suggests that birch and aspen harvested for biomass energy can be significantly expanded in our analysis area.

It is important to note that the harvest activities we describe in this study area mostly produced the first rotation under management. The second-growth generated after those harvests have not yet reached a mature stage or even the age classes projected for short rotations. Although further monitoring is essential, this early investigation is useful to determine whether management to date is within the intensity that can sustain both ecological and economical values of the boreal forest.

This initial compilation of harvest volume, which we report here, is underestimated because we were only able to compile records on volume harvested for about $90 \%$ of the total area harvested. Records of volume harvested are missing for many units in the Delta (26\% of the total area harvested) and Tok ( $72 \%$ of the total area harvested) areas. The Tok management area has overall lower standing volumes per area than the other areas $\left(48 \mathrm{~m}^{3} \cdot \mathrm{ha}^{-1}\right.$ versus $68-79 \mathrm{~m}^{3} \cdot \mathrm{ha}^{-1}$, respectively). We did not estimate the missing harvest volume data because the variability and lack of information on harvesting methods and harvested volume by species would introduce high variability into the estimate.

\subsection{Accessibility}

Access is one of the major constraints of forest harvest management in Interior Alaska [14]. Even though vast forest land has remained unharvested, most areas are not road accessible. On state forest lands, 1010 out of 1128 (or 90\%) of harvest units were within $1 \mathrm{~km}$ of a road, and $99 \%$ of harvest units were within $4 \mathrm{~km}$ of a road. This is not a surprising result, as access roads are essential for timber harvesting. An exception is ice road (frozen river) access during winter, which was not included as a "road" in our analysis. However, only $15 \%$ of the area on the state forest lands was located within $1 \mathrm{~km}$ of any type of road, including winter roads (not ice roads), and over $60 \%$ of the area was located more than $4 \mathrm{~km}$ from existing an road network. This apparently caused a concentration of harvest activities on the small road-accessible portion of state forest lands. Building roads is expensive and accessible forest areas will likely remain limited for the foreseeable future. As a result, sustainability of the accessible forest areas needs to be assessed.

Harvest intensity relative to the growth (annual volume harvested divided by annual volume growth) was highest in the most accessible forest areas (within $1 \mathrm{~km}$ of a road), except in the Delta management area, in which the highest concentration occurred in the areas within $2 \mathrm{~km}$ of a road (Table 8). Even though the intensity was highest in the areas near a road, only in the Kantishna management area did the annual volume harvested exceeded the annual volume growth in those areas (Table 8). Harvest intensity was higher in the Fairbanks and Kantishna management areas (Table 8), partly due to more complete records in those areas than Delta and Tok. However, during some years, the volume harvested exceeded the annual volume growth in all of the management areas (Table 8). The numbers of years that exceeded the annual growth were greater in the areas nearer a road, and were much greater in the Fairbanks management area than other management areas (Table 8).

The volume growth used in this study was underestimated, because we did not include any pole timber types, which contain a lot of sawlogs and are likely to be harvestable. Obviously, it is essential to have better growth estimates for more accurate and precise planning of sustainable forest harvest management. 
Table 8. Total volume, volume harvested, maximum annual volume harvested, mean annual volume harvested, annual volume harvested divided by annual volume growth, and the number of years exceeding annual volume growth of white spruce sawlogs in each management areas on state forest lands.

\begin{tabular}{|c|c|c|c|c|c|}
\hline & \multicolumn{5}{|c|}{ Distance to the Nearest Road } \\
\hline & $\leq \mathbf{1 ~ k m ~}$ & $\leq 2 \mathrm{~km}$ & $\leq 3 \mathrm{~km}$ & $\leq 4 \mathrm{~km}$ & Any Distance \\
\hline & \multicolumn{5}{|c|}{ Fairbanks } \\
\hline Total volume $\left(\mathrm{m}^{3}\right)$ & $3,088,004$ & $3,473,083$ & $3,758,083$ & $3,923,937$ & $4,677,894$ \\
\hline Volume harvested $\left(\mathrm{m}^{3}\right)$ & 745,745 & 764,233 & 766,744 & 766,744 & 766,744 \\
\hline Max. annual volume harvested $\left(\mathrm{m}^{3}\right)$ & 94,131 & 94,131 & 94,131 & 94,131 & 94,131 \\
\hline Mean annual volume harvested $\left(\mathrm{m}^{3}\right)$ & 18,189 & 18,640 & 18,701 & 18,701 & 18,701 \\
\hline Annual growth & 19,532 & 21,983 & 23,689 & 24,742 & 29,193 \\
\hline Volume harvested/growth $(\%)$ & $93.1 \%$ & $84.8 \%$ & $78.9 \%$ & $75.6 \%$ & $64.1 \%$ \\
\hline \multirow[t]{2}{*}{ \# years exceeding annual growth } & 12 & 11 & 11 & 11 & 8 \\
\hline & \multicolumn{5}{|c|}{ Kantishna } \\
\hline Total volume $\left(\mathrm{m}^{3}\right)$ & 155,122 & 279,016 & 295,510 & 324,083 & $1,983,733$ \\
\hline Volume harvested $\left(\mathrm{m}^{3}\right)$ & 39,215 & 40,841 & 40,841 & 46,618 & 46,618 \\
\hline Max. annual volume harvested $\left(\mathrm{m}^{3}\right)$ & 29,657 & 29,657 & 29,657 & 35,434 & 35,434 \\
\hline Mean annual volume harvested $\left(\mathrm{m}^{3}\right)$ & 956 & 996 & 996 & 1137 & 1137 \\
\hline Annual growth & 895 & 1608 & 1702 & 1867 & 11,668 \\
\hline Volume harvested/growth (\%) & $106.9 \%$ & $61.9 \%$ & $58.5 \%$ & $60.9 \%$ & $9.7 \%$ \\
\hline \multirow[t]{2}{*}{ \# years exceeding annual growth } & 2 & 2 & 2 & 2 & 1 \\
\hline & \multicolumn{5}{|c|}{ Delta } \\
\hline Total volume $\left(\mathrm{m}^{3}\right)$ & $1,078,417$ & $1,471,422$ & $1,726,615$ & $1,824,962$ & $2,867,983$ \\
\hline Volume harvested $\left(\mathrm{m}^{3}\right)$ & 74,199 & 108,137 & 109,471 & 109,471 & 121,339 \\
\hline Max. annual volume harvested $\left(\mathrm{m}^{3}\right)$ & 11,048 & 21,923 & 21,923 & 21,923 & 21,923 \\
\hline Mean annual volume harvested $\left(\mathrm{m}^{3}\right)$ & 1810 & 2637 & 2670 & 2670 & 2959 \\
\hline Annual growth & 6393 & 8761 & 10,260 & 10,833 & 17,407 \\
\hline Volume harvested/growth (\%) & $28.3 \%$ & $30.1 \%$ & $26.0 \%$ & $24.6 \%$ & $17.0 \%$ \\
\hline \multirow[t]{2}{*}{ \# years exceeding annual growth } & 4 & 4 & 3 & 3 & 1 \\
\hline & \multicolumn{5}{|c|}{ Tok } \\
\hline Total volume $\left(\mathrm{m}^{3}\right)$ & 299,885 & 520,014 & 615,415 & 689,058 & 916,238 \\
\hline Volume harvested $\left(\mathrm{m}^{3}\right)$ & 21,830 & 27,266 & 27,266 & 27,266 & 27,266 \\
\hline Max. annual volume harvested $\left(\mathrm{m}^{3}\right)$ & 9659 & 10,415 & 10,415 & 10,415 & 10,415 \\
\hline Mean annual volume harvested $\left(\mathrm{m}^{3}\right)$ & 532 & 665 & 665 & 665 & 665 \\
\hline Annual growth & 1868 & 3221 & 3808 & 4263 & 5681 \\
\hline Volume harvested/growth (\%) & $28.5 \%$ & $20.6 \%$ & $17.5 \%$ & $15.6 \%$ & $11.7 \%$ \\
\hline \# years exceeding annual growth & 4 & 3 & 2 & 2 & 2 \\
\hline
\end{tabular}

\section{Conclusions}

In central Interior Alaska, forest harvest management has been low-input and has relied heavily on natural regeneration (Table 6). The primary reason that the low-input management has historically produced very small profit margins is mainly due to minimal local demand, distance from major markets, limited access, low product value, and high cost of labor [14]. Based on our analysis, forest harvesting in central Interior Alaska on average is sustainable. However, it is important to recognize a few issues in the current harvest management regime due to the limited infrastructures and facilities in the study area.

Historical harvest activities were concentrated on the road-accessible area and in the mature white spruce type (Figure 4, Table 8). Obviously, continued harvest of particular forest types in road-accessible areas (assuming road networks will not expand) could deplete important forest structures, particularly older (productive) white spruce types. The road-accessible forest areas also provide the public with opportunities to obtain not only timber but also non-timber products, particularly the harvesting of subsistence wildlife and plant species such as berries. Increasing timber harvests can systematically decrease public access to non-timber forest products [52]. As a result, harvest activities need to be 
distributed geographically and by species in a way that prevents the reduction of forest productivity or loss of ecosystem services.

We note the existence of two options to expand timber production while providing for sustained yields of forest products in the study region: expanding road networks, and diversifying harvest species to include more broadleaf. The first option of road network expansion, although expensive and challenging, will provide access to additional stands containing harvestable timber. For this option, we suggest two potential state forest areas that could provide increased harvests that contain a large amount and continuous area of white spruce, birch, and aspen (Figure 5): the Kantishna area, and the north part of the Fairbanks area. Although the Kantishna area is remote from the existing road system, potentially it could be accessed by river in winter, assuming the river continues to freeze hard enough for vehicles to drive on. Mature white spruce occurs mostly along the river, but extensive road construction would be required for birch and aspen harvest in the area. The north part of the Fairbanks area, meanwhile, contains a large area of birch-dominated stands.

The second option would be a shift in harvest and utilization from white spruce to other species, especially birch and aspen. The increasing demand for wood biomass for energy generation potentially could make the harvest of other species and the use of other harvest methods more feasible. Even in the present situation, white spruce is still often preferred because mature white spruce stands contain the highest volumes, making white spruce harvesting more profitable than other species in central Interior Alaska. In addition, there are few facilities that utilize small diameter broadleaf. It is obvious that the study of economic limitations and opportunities is a priority for the expansion of broadleaf harvesting. However, this study demonstrates that it is worthwhile to consider investing in equipment and facilities that optimize harvesting and processing of smaller diameter trees, especially birch and aspen, due to the large margins between the harvest levels and allowable-cut levels (Table 7).

Another limitation and uncertainty of broadleaf harvesting is regeneration following broadleaf harvest and its effects on the forest succession of white spruce stands. Although regeneration following white spruce harvesting has been examined and been found to be successful without intensive management due to its small scale and focus, broadleaf harvesting has not been assessed in the study area. However, broadleaf harvesting has some apparent advantages over white spruce harvesting. Alaska birch and aspen regenerate more successfully and grows faster than white spruce in Interior Alaska boreal forest $[46,53]$. These growth characteristics of birch and aspen reduce the area required to sustain harvest volume in a biomass production system (wood biomass harvest) compared to a spruce-based system (traditional sawlog harvest). In addition, birch and aspen regeneration do not face the same limitations as white spruce natural regeneration, such as infrequent large and/or viable cone crops [40,41]. Increasing the harvest of birch and aspen could also reduce the demand for mature white spruce for biomass energy, reducing the historical focus on white spruce harvesting within the accessible land base. Finally, broadleaf species are more resistant to wildfire than white spruce. Wildfire in Interior Alaska has become more intense, severe, and frequent under climate warming, and it is likely to intensify more in the future [54]. In such a situation, broadleaf will remain relatively resilient, while white spruce will decrease substantially through wildfire.

A potential issue with increased broadleaf harvesting is an eventual reduction of white spruce stands across the landscape. In the Alaska boreal forest, broadleaf often dominates for a few decades after disturbance, while white spruce regenerates slowly under the broadleaf canopy. Broadleaf eventually dies, and the white spruce underneath takes over the canopy. If broadleaf stands are harvested, the succession may start over again from broadleaf dominance and reduce the potential future white spruce stands. As a result, regeneration and succession after broadleaf harvesting must be assessed before increasing broadleaf harvesting substantially. If it is assumed that road access will not increase significantly in the future, and that broadleaf harvesting will remain less profitable, harvesting intensities relative to growth need to be closely monitored, particularly in road-accessible areas. 
(a)

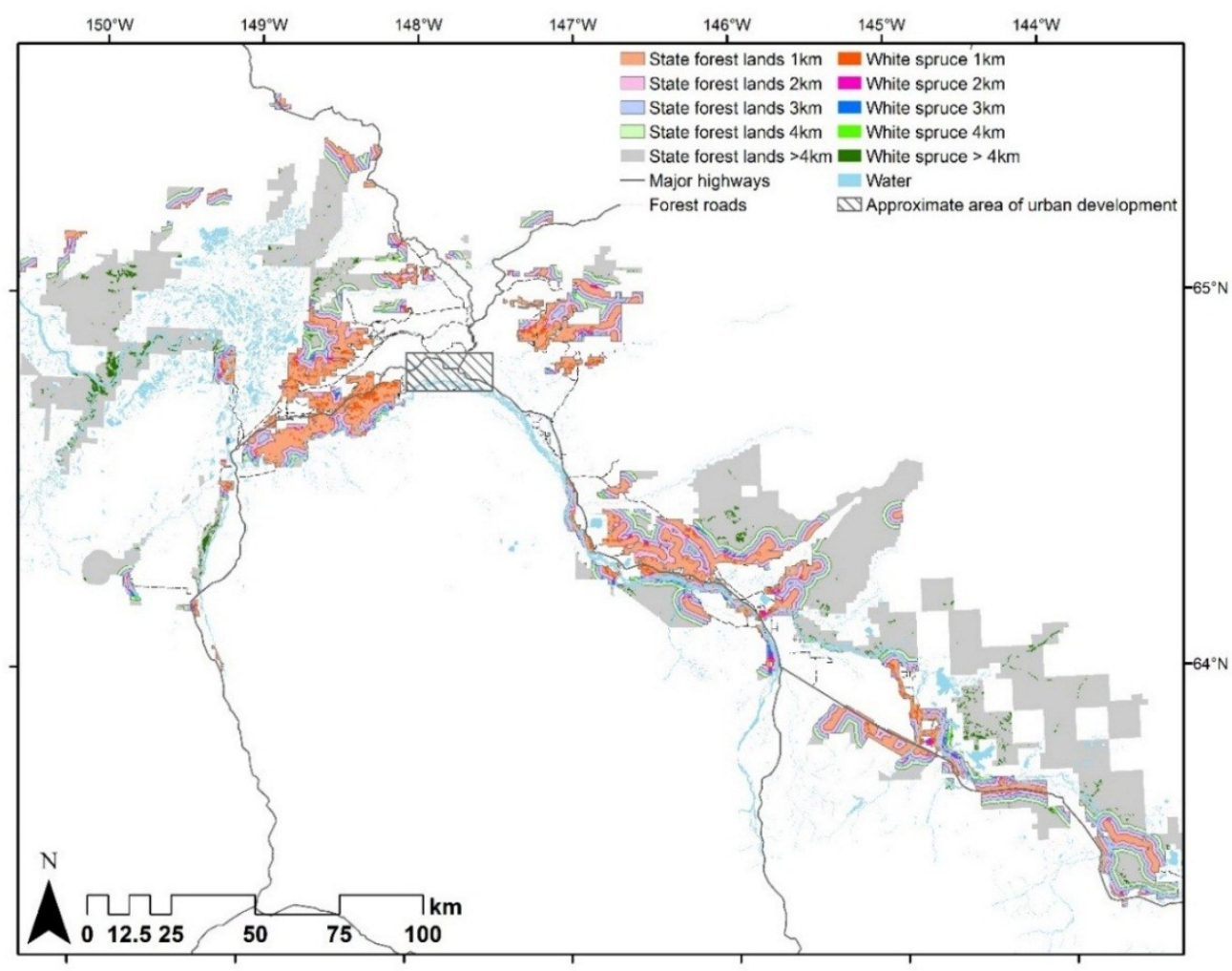

(b)

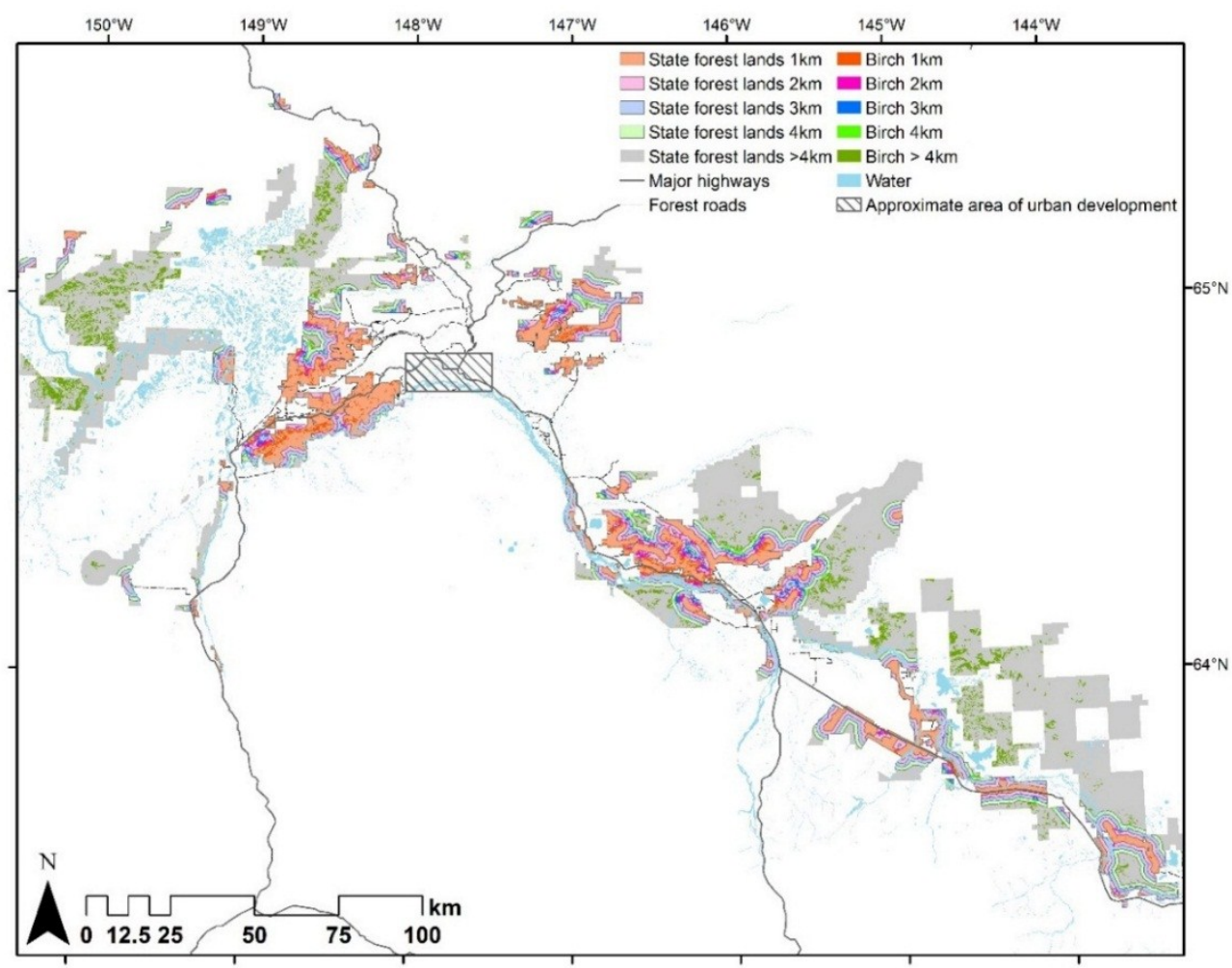

Figure 5. Distribution of (a) mature white spruce and (b) birch-dominated stands in zones within 1, 2, 3,4 , and $>4 \mathrm{~km}$ of road network. Birch dominated stands include mixed birch-aspen stands as well. 
However, rapid climate change may present new challenges and opportunities in sustainable timber production. A majority of state forest lands fall under intensive fire management categories, which fire has suppressed relatively effectively [55]. In those areas where fires are suppressed, flammable fuel builds up that leads to high-intensity and/or large-scale fires in the future. Forest harvest management could emulate natural fire disturbance and reduce fuel amounts to prevent intensive and large-scale fires in the future [18]. However, fires cannot be controlled completely. As a result, sustainable forest harvest management must consider the effects of fires, such as the needs of salvage logging and a potential reduction of harvestable timber volumes due to damages.

Supplementary Materials: The following are available online at http://www.mdpi.com/1999-4907/10/6/484/s1, Table S1: Mean DBH (cm) of each specie for each vegetation type (Volume Unit 1 (Fairbanks, Kantishna and Delta management areas)). Table S2: Mean DBH $(\mathrm{cm})$ of each species in each vegetation types (Volume Unit 2 (Tok management area)).

Author Contributions: Conceptualization, M.M. and G.J.; methodology, M.M.; software, M.M.; validation, M.M.; formal analysis, M.M.; investigation, M.M.; resources, M.M.; data curation, M.M.; writing—original draft preparation, M.M.; writing-review and editing, M.M. and G.J.; visualization, M.M.; supervision, G.J.; project administration, G.J.; funding acquisition, G.J.

Funding: This research was funded by a project BAK LAP (Boreal Alaska-Learning, Adaptation, Production) supported by appropriation to the Alaska Department of Natural Resources Division of Forestry, the McIntire Stennis Cooperative Forestry Research Program (ALK13-04), and the Bonanza Creek Long-Term Ecological Research program funded by the National Science Foundation (DEB-1026415).

Acknowledgments: We would like to thank the Fairbanks, Delta, and Tok areas of the Alaska Department of Natural Resources Division of Forestry, and the Tanana Chiefs Conference for providing the data.

Conflicts of Interest: The authors declare no conflict of interest.

\section{References}

1. Gauthier, S.; Bernier, P.; Kuuluvainen, T.; Shvidenko, A.; Schepaschenko, D. Boreal forest health and global change. Science 2015, 349, 819-822. [CrossRef] [PubMed]

2. Östlund, L.; Zackrisson, O.; Axelsson, A.-L. The history and transformation of a Scandinavian boreal forest landscape since the 19th century. Can. J. 1997, 27, 1198-1206. [CrossRef]

3. Johnson, E.A.; Miyanishi, K. The boreal forest as a cultural landscape. Annals of the New York Academy of Sciences 2012, 1249, 151-165. [CrossRef] [PubMed]

4. Chaudhary, A.; Burivalova, Z.; Koh, L.P.; Hellweg, S. Impact of Forest Management on Species Richness: Global Meta-Analysis and Economic Trade-Offs. Sci. Rep. 2016, 6, 23954. [CrossRef] [PubMed]

5. FAO. Global Forest Resources Assessment 2015. Available online: http://www.fao.org/forest-resourcesassessment/past-assessments/fra-2015/en/ (accessed on 3 February 2019).

6. Murphy, P.J.; Mudd, J.P.; Stocks, B.J.; Kasischke, E.S.; Barry, D.; Alexander, M.E.; French, N.H.P. Historical fire records in the north american boreal forest. In Fire, Climate Change, and Carbon Cycling in the Boreal Forest; Kasischke, E.S., Stocks, B.J., Eds.; Springer: New York, NY, USA, 2000.

7. Chapin, F.; Fastie, C.; Viereck, L.; Ott, R.; Adams, P.; Mann, D.; Van Cleve, K.; Johnstone, J. Successional processes in the Alaskan boreal forest. In Alaska's Changing Boreal Forest; Chapin, F., Oswood, M., Van Cleve, K., Viereck, L., Verbyla, D., Eds.; Oxford University Press: New York, NY, USA, 2006; pp. 100-120.

8. Cyr, D.; Gauthier, S.; Bergeron, Y.; Carcaillet, C. Forest management is driving the eastern North American boreal forest outside its natural range of variability. Front. Ecol. 2009, 7, 519-524. [CrossRef]

9. Bergeron, Y. Is regulated even-aged management the right strategy for the Canadian boreal forest? For. Chron. 2004, 80, 458-462. [CrossRef]

10. Bergeron, Y.; LeDuc, A.; Harvey, B.; Gauthier, S. Natural fire regime: A guide for sustainable management of the Canadian boreal forest. Silva Fenn. 2002, 36, 81-95. [CrossRef]

11. Burton, P.J.; Bergeron, Y.; Bogdanski, B.E.C.; Juday, G.P.; Kuuluvainen, T.; McAfee, B.J.; Ogden, A.; Teplyakov, V.K.; Alfaro, R.I.; Francis, D.A.; et al. Sustainability of boreal forests and forestry in a changing environment. In Forests and Society—Responding to Global Drivers of Change; Mery, G., Katila, P., Galloway, G., Alfaro, R.I., Kanninen, M., Lobovikov, M., Varjo, J., Eds.; International Union of Forest Research Organizations (IUFRO): Vienna, Austria, 2010; pp. 249-282. 
12. Potapov, P.; Yaroshenko, A.; Turubanova, S.; Dubinin, M.; Laestadius, L.; Thies, C.; Aksenov, D.; Egorov, A.; Yesipova, Y.; Glushkov, I.; et al. Mapping the World's Intact Forest Landscapes by Remote Sensing. Ecol. Soc. 2008, 13, 13. [CrossRef]

13. Potapov, P.; Hansen, M.C.; Laestadius, L.; Turubanova, S.; Yaroshenko, A.; Thies, C.; Smith, W.; Zhuravleva, I.; Komarova, A.; Minnemeyer, S.; et al. The last frontiers of wilderness: Tracking loss of intact forest landscapes from 2000 to 2013. Sci. Adv. 2017, 3, e1600821. [CrossRef]

14. Wurtz, T.; Ott, R.; Maisch, J. Timber harvest in interior Alaska. In Alaska's Changing Boreal Forest; Chapin, F., Oswood, M., Van Cleve, K., Viereck, L., Verbyla,, D., Eds.; Oxford University Press: New York, NY, USA, 2006.

15. Chapin, F.S.; McGuire, A.D.; Ruess, R.W.; Hollingsworth, T.N.; Mack, M.C.; Johnstone, J.F.; Kasischke, E.S.; Euskirchen, E.S.; Jones, J.B.; Jorgenson, M.T.; et al. Resilience of Alaska's boreal forest to climatic change. Can. J. For. Res. 2010, 40, 1360-1370. [CrossRef]

16. Barber, V.A.; Juday, G.P.; Finney, B.P. Reduced growth of Alaskan white spruce in the twentieth century from temperature-induced drought stress. Nat. Cell Boil. 2000, 405, 668-673. [CrossRef] [PubMed]

17. McGuire, A.D.; Ruess, R.W.; Lloyd, A.; Yarie, J.; Clein, J.S.; Juday, G.P. Vulnerability of white spruce tree growth in interior Alaska in response to climate variability: Dendrochronological, demographic, and experimental perspectives. Can. J. For. Res. 2010, 40, 1197-1209. [CrossRef]

18. Chapin, F.S.; Trainor, S.F.; Huntington, O.; Lovecraft, A.L.; Zavaleta, E.; Natcher, D.C.; McGuire, A.D.; Nelson, J.L.; Ray, L.; Calef, M.; et al. Increasing Wildfire in Alaska's Boreal Forest: Pathways to Potential Solutions of a Wicked Problem. BioScience 2008, 58, 531-540. [CrossRef]

19. Plentovich, D.; Alaska Energy Authority, Anchorage, AK, USA. Personal communication, 2015.

20. Fresco, N.; Chapin, F.S. Assessing the potential for conversion to biomass fuels in interior Alaska. In Assessing the Potential for Conversion to Biomass Fuels in Interior Alaska; USDA Forest Service: Portland, OR, USA, 2009; Volume 579, pp. 1-56.

21. Wurtz, T.L.; Gasbarro, A.F. A brief history of wood use and forest management in Alaska. For. Chron. 1996, 72, 47-50. [CrossRef]

22. Roessler, J.S.; Packee, E.C. Disturbance history of the tanana river basin in Alaska: Management implications. Proceedings of Annual Tall Timbers Fire Ecology Conference, San Diego, CA, USA, 27 November-1 December 2000; pp. 46-57.

23. Labau, V.J.; van Hees, W. An inventory of Alaska's boreal forests: Their extent, condition, and potential use. Proceedings of The International Symposium on Boreal Forests: Condition, Dynamics, Anthropogenic Effects, Archangelsk, Russia, 16-26 July 1990; pp. 30-39.

24. Wendler, G.; Shulski, M. A Century of Climate Change for Fairbanks, Alaska. ARCTIC 2009, 62, $295-300$. [CrossRef]

25. Shulski, M.; Wendler, G. The Climate of Alaska; University of Alaska Press: Fairbanks, AK, USA, 2007.

26. Hanson, D. Timber Inventory of State Forest Lands in the Tanana Valley 2013. Available online: http: //forestry.alaska.gov/timber/forestinventories (accessed on 24 April 2017).

27. Putman, W.; Tanana Chiefs Co nference Inc. Forest Stewardship Plan for Toghotthele Corporation Nenana, Alaska. 2007; (unpublished).

28. AKDOF. Forest Management Database; (unpublished); Alaska Department of Natural Resources Division of Forestry, Ed.; Alaska Division of Forestry: Fairbanks, AK, USA, 2013.

29. Tanana Chiefs Conferenc e Inc. Tcc timbersale database. Tanana Chiefs Conference, Ed.; Fairbanks, AK, USA.

30. Alaska Interagency Coordination Center. Fire history in Alaska. Alaska Interagency Coordination Center. Available online: http://fire.ak.blm.gov/ (accessed on 3 April 2017).

31. Alaska Department of Natural Resources. Tanana Valley State Forest Management Plan. Alaska Department of Natural Resources, Ed.; Available online: http://forestry.alaska.gov/management/tvsfmp (accessed on 24 April 2017).

32. Bonan, G. Ecological Climatology: Concepts and Applications; Cambridge University Press: New York, NY, USA, 2016.

33. Van Cleve, K.; Yarie, J. Interaction of Temperature, Moisture, and Soil Chemistry in Controlling Nutrient Cycling and Ecosystem Development in the Taiga of Alaska; Springer Nature: New York, NY, USA, 1986; Volume 57, pp. 160-189.

34. Viereck, L.A.; Dyrness, C.T.; Van Cleve, K.; Foote, M.J. Vegetation, soils, and forest productivity in selected forest types in interior Alaska. Can. J. 1983, 13, 703-720. [CrossRef] 
35. Yarie, J. Forest fire cycles and life tables: A case study from interior Alaska. Can. J. 1981, 11, 554-562. [CrossRef]

36. Lynch, J.A.; Clark, J.S.; Bigelow, N.H.; Edwards, M.E.; Finney, B.P. Geographic and temporal variations in fire history in boreal ecosystems of Alaska. J. Geophys. Res. Biogeosciences 2002, 108, 1-17. [CrossRef]

37. Johnstone, J.F.; Kasischke, E.S. Stand-level effects of soil burn severity on postfire regeneration in a recently burned black spruce forest. Can. J. 2005, 35, 2151-2163. [CrossRef]

38. Haeussler, S.; Bedford, L.; LeDuc, A.; Bergeron, Y.; Kranabetter, J. Silvicultural disturbance severity and plant communities of the southern Canadian boreal forest. Silva Fenn. 2002, 36, 307-327. [CrossRef]

39. Macdonald, S.E.; Hogg, E.H.; Lieffers, V.J. Ecology of and control strategies for Calamagrostis canadensis in boreal forest sites. Can. J. 1993, 23, 2070-2077.

40. Nienstaedt, H.; Zasada, J.C. Picea glauca (moench) voss, white spruce. In Silvics of North America: Volume 1. Conifers. Agriculture Handbook 654; Burns, R.M., Honkala, B.H., Eds.; USDA Forest Service: Washington, DC, USA, 1990; Volume 1, pp. 204-226.

41. Roland, C.A.; Schmidt, J.H.; Johnstone, J.F. Climate sensitivity of reproduction in a mast-seeding boreal conifer across its distributional range from lowland to treeline forests. Oecologia 2014, 174, 665-677. [CrossRef]

42. Zasada, J. Production, dispersal and germination of white spruce and paper birch and first-year seedling establishment after the rosie creek fire. In Early Results of the Rosie Creek Fire Research Project 1984; Juday, G., Dyrness, C., Eds.; University of Alaska Fairbanks, Agricultural and Forestry Experiment Station: Fairbanks, AK, USA, 1985.

43. Juday, G.P.; Barber, V.; Rupp, S.; Zasada, J.; Wilmking, M. A 200-year perspective of climate variability and the response of white spruce in interior alaska. In Climate Variability and Ecosystem Response at Long-Term Ecological Research Sites; Oxford University Press: New York, NY, USA, 2003.

44. Youngblood, A.P.; Max, T.A.; Pacific Northwest Research Station (Portland, Or.). Dispersal of White Spruce Seed on Willow Island in Interior Alaska; USDA Forest Service Research Paper PNW 443; US Forest Service: Washington, DC, USA, 1992.

45. Alaska Division of Forestry. Alaska Division of Forestry Overview. Available online: http://forestry.alaska. gov/overview (accessed on 31 January 2019).

46. Morimoto, M.; Juday, G.P.; Young, B.D. Early tree regeneration is consistent with sustained yield in low-input boreal forest management in Alaska. Ecol. Manag. 2016, 373, 116-127. [CrossRef]

47. Morimoto, M.; Juday, G.; Young, B. Clearcutting and site preparation, but not planting, promoted early tree regeneration in boreal Alaska. Forests 2017, 8, 12. [CrossRef]

48. Youngblood, A.; Cole, E.; Newton, M. Survival and growth response of white spruce stock types to site preparation in Alaska. Can. J. 2011, 41, 793-809. [CrossRef]

49. Granström, A. Fire Management for Biodiversity in the European Boreal Forest. Scand. J. 2001, 16, 62-69. [CrossRef]

50. Wagner, R.G.; Newton, M.; Cole, E.C.; Miller, J.H.; Shiver, B.D. The role of herbicides for enhancing forest productivity and conserving land for biodiversity in North America. Wildl. Soc. 2004, 32, 1028-1041. [CrossRef]

51. Juday, G.P. The rosie creek fire. Agroborealis 1985, 17, 11-20.

52. Usher, M.B.; Callaghan, T.V.; Gilchrist, G.; Heal, O.W.; Juday, G.P.; Loeng, H.; Muir, M.A.K.; Prestrud, P. Principles of conserving the arctic's biodiversity. In Arctic Climate Impact Assessment; Cambridge University Press: New York, NY, USA, 2005; pp. 539-596.

53. Youngblood, A. Development patterns in young conifer-hardwood forests of interior Alaska. J. Veg. Sci. 1995, 6, 229-236. [CrossRef]

54. Bachelet, D.; Lenihan, J.; Drapek, R.; Neilson, R.; Kittel, T. Simulating the response of natural ecosystems and their fire regimes to climatic variability in Alaska. Can. J. 2005, 35, 2244-2257. [CrossRef]

55. Dewilde, L.; Chapin, F.S.; Iii, F.S.C. Human Impacts on the Fire Regime of Interior Alaska: Interactions among Fuels, Ignition Sources, and Fire Suppression. Ecosystems 2006, 9, 1342-1353. [CrossRef] 